\section{Rapid tracheal intubation with atracurium: the timing principle}

Kwong Fah Koh MMBS MMed Anaes,

Fun Gee Chen MmBS FFARACS MMed Anaes
The "Timing Principle" utilises a single bolus of nondepolarising neuromuscular blocking drug followed by thiopentone given at the onset of clinical weakness. The purpose of this study was to compare the intubating conditions after succinylcholine and after atracurium used according to the "timing principle." Eighty patients were randomly assigned to four groups of 20. Three study groups were given atracurium 0.5, 0.75 or $I \mathrm{mg} \cdot \mathrm{kg}^{-1}$ (Groups I, II and III respectively) and the control group (Group IV) received succinylcholine 1.5 $\mathrm{mg} \cdot \mathrm{kg}^{-1}$. The study groups received fentanyl $1 \mathrm{\mu g} \cdot \mathrm{kg}^{-1}$, atracurium three minutes later, followed by thiopentone 4-6 $\mathrm{mg} \cdot \mathrm{kg}^{-1}$ at the onset of ptosis. The control group had a defasciculating dose of atracurium $\left(0.025 \mathrm{mg} \cdot \mathrm{kg}^{-1}\right)$ and fentanyl (1 $\mu \mathrm{g} \cdot \mathrm{kg}^{-1}$ ) followed by thiopentone (4-6 $\mathrm{mg} \cdot \mathrm{kg}^{-1}$ ) and succinylcholine three minutes later. The trachea was intubated one minute after thiopentone was given. The intubating conditions were then graded by a laryngoscopist who was unaware of the induction sequence. All patients were interviewed on the day after surgery. Intubation scores of patients in Group I were worse than in Groups II, III and IV $(P<0.005)$ but there were no differences between Groups II, III and IV. The technique was not associated with severe haemodynamic changes. All patients, except one were able to cough well afier administration of atracurium, before induction of anaesthesia with thiopentone. Patients were generally satisfied with this method of induction. It is concluded that atracurium, when used according to the timing principle, can be an alternative to succinylcholine during rapid-sequence induction.

\section{Key words}

INTUBATION, TRACHEAL: technique;

NEUROMUSCULAR RELAXANTS: atracurium, succinylcholine.

From the Department of Anaesthesia, National University

Hospital, 5 Lower Kent Ridge Road, Singapore 0511.

Address correspondence to: Dr. Kwong Fah Koh, Dept of

Anaesthesia, National University Hospital, 5 Lower Kent Ridge

Road, Singapore 0511.

Accepted for publication 30th April, 1994.
Le principe de la synchronisation désigne l'utilisation d'un bolus de myorelaxant non dépolarisant suivi du thiopentone administré lorsque la faiblesse musculaire se manifeste. Cette étude vise à comparer les conditions d'intubation procurées par la succinylcholine et à l'atracurium administré selon le principe de la synchronisation. Quatre-vingts patients sont répartis au hasard en quatre groupes de vingt. Trois groupes reçoivent atracurium 0,5, 0,75 ou $1 \mathrm{mg} \cdot \mathrm{kg}^{-1}$ (Groupes I, II et III) et le groupe contrôle reçoit (Groupe IV) de la succinylcholine 1,5 $m g \cdot \mathrm{kg}^{-1}$. Les groupes d'étude reçoivent fentanyl $1 \mu \mathrm{g} \cdot \mathrm{kg}^{-1}$, atracurium trois minutes plus tard, suivi par thiopentone 4-6 $m g \cdot \mathrm{kg}^{-1}$ à l'apparition de la ptose palpébrale. Le groupe contrôle reçoit une dose d'atracurium $\left(0,025 \mathrm{mg} \cdot \mathrm{kg}^{-1}\right)$ pour prévenir les fasciculations et de fentanyl $\left(1 \mu \mathrm{g} \cdot \mathrm{kg}^{-1}\right)$ suivis $\mathrm{du}$ thiopentone (4-6 $\mathrm{mg} \cdot \mathrm{kg}^{-1}$ ) et de la succinylcholine trois minutes plus tard. La trachée est intubée une minute après l'administration de thiopentone. Les conditions dintubation sont alors cotées par un anesthésiste ignorant de la séquence de linduction. Tous les patients sont questionnés le jour suivant. Pour lintubation, les scores des patients du Groupe I sont moins favorables que ceux du. Groupe II, III et IV $(P<0,005)$ mais on ne trouve pas de différences entre les Groupes II, III et IV. La technique ne s'accompagne pas de changements hémodynamiques majeurs. Tous les patients à l'exception d'un seul sont capables de tousser aisément aprés l'administration d'atracurium avant le thiopentone. En général, les patients se déclarent satisfaits de cette méthode dinduction. En conclusion, l'atracurium administré selon le principe de la synchronisation représente pour lïnduction à séquence rapide une alternative valable à la succinylcholine.

Rapid-sequence induction of anaesthesia with succinylcholine and orotracheal intubation is an established technique in patients who are at risk of aspiration of gastric contents during anaesthesia. Although succinylcholine is a reliable agent, due to its rapid onset, it has numerous side effects making its use contraindicated in certain situations. ' This has led to the search for newer muscle relaxants with similar onset of action. Rocuronium (ORG 9426) has shown good potential and is currently undergoing clinical evaluation. ${ }^{2,3}$ Until these agents become 
widely available, clinicians have modified techniques of administering established non-depolarising muscle relaxants in an attempt to reduce its onset time. The priming technique using divided doses of a non-depolarising muscle relaxant has been advocated as an alternative to succinylcholine during rapid-sequence intubation. ${ }^{4}$ However, intubating conditions obtained have been inconsistent ${ }^{5}$ and have been associated with diplopia, difficulty in swallowing, ${ }^{6}$ and even pulmonary aspiration. ${ }^{7}$ Megadosing, the administration of a massive overdose of blocking agent has been shown to provide excellent intubating condition $^{8}$ but the duration of neuromuscular blockade is also greatly prolonged. ${ }^{9}$ Recently, the timing principle 10,11 using vecuronium has been studied and was noted to produce intubating conditions comparable with those after succinylcholine. This technique utilises a single bolus of vecuronium followed by thiopentone timed at the onset of clinical weakness. Atracurium has the advantage over vecuronium in its lack of accumulation ${ }^{12}$ and less residual neuromuscular block. ${ }^{13}$ As it has lower potency than vecuronium, theoretically it would have a more rapid onset time. ${ }^{14,15}$ We evaluated the timing principle using atracurium and modified the technique to determine if atracurium could produce intubating conditions comparable with those of succinylcholine.

\section{Methods}

This study was approved by our hospital's ethics committee. Informed consent was obtained from 80 patients with ASA physical status I and II undergoing elective surgery. Exclusion criteria included those patients aged $<18$ or $>60 \mathrm{yr}$, pregnancy, asthma, potentially difficult intubation, those at risk of aspiration and any patient with a history of sensitivity or who had contraindications to medications used in the study. Patients were randomly assigned to one of four groups by drawing lots. The patients in the three study groups, Groups I, II and III, received atracurium $0.5 \mathrm{mg} \cdot \mathrm{kg}^{-1}, 0.75 \mathrm{mg} \cdot \mathrm{kg}^{-1}$ or 1 $\mathrm{mg} \cdot \mathrm{kg}^{-1}$ respectively. Those in Group IV received suocinylcholine $1.5 \mathrm{mg} \cdot \mathrm{kg}^{-1}$ and served as the control group.

The patients were not premedicated. In the operating theatre, an ECG (Hewlett Packard HP 7835A), automated blood pressure cuff (Dinamap 1846SX) and pulse oximeter (Nellcor N-100E) were applied. An 18G or $20 \mathrm{G}$ peripheral intravenous cannula (Venflon Viggospectramed) was inserted on the dorsum of the hand. The patients were warned before induction that they may experience some weakness before the onset of anaesthesia. Fentanyl $1 \mu \mathrm{g} \cdot \mathrm{kg}^{-1} \dot{i v}$ was then given and preoxygenation was carried out for the next three minutes. The patients in the study groups were instructed to keep their eyes wide open during induction. Atracurium 0.5 $\mathrm{mg} \cdot \mathrm{kg}^{-1}, 0.75 \mathrm{mg} \cdot \mathrm{kg}^{-1}$ or $1 \mathrm{mg} \cdot \mathrm{kg}^{-1}$ was then given over ten seconds. Onset of clinical weakness was judged by the development of ptosis which was when furrows were seen forming on the patient's forehead. (The furrows represented attempts by the patient to use the occipitofrontalis to overcome ptosis due to onset of neuromuscular blockade of the levator palpebrae muscle). When this occurred, the patients were asked to cough to provide a gross assessment of the ability to protect their airway ${ }^{2}$ The quality of cough was assessed as normal, weak or absent. The time of onset of ptosis was noted. Intravenous thiopentone $4-6 \mathrm{mg} \cdot \mathrm{kg}^{-1}$ was given as a bolus over the next five seconds. The patient's lungs were ventilated with $100 \%$ oxygen and $60 \mathrm{sec}$ after the thiopentone bolus, the trachea was intubated by a laryngoscopist who was blinded to the induction technique

The intubating conditions were graded as follows: 3 - excellent (easy passage of tube without coughing); 2 - satisfactory (passage of tube with slight coughing, bucking or both); 1 - fair (passage of tube with moderate coughing, bucking or both); and 0 - poor (intubation was not possible). ${ }^{16}$

The patient's blood pressure and heart rate were recorded every minute from just before fentanyl was given till five minutes after intubation. Further haemodynamic variables were not analysed thereafter as other factors such as the start of surgical stimulus, confounded the results. Presence of flushing or bronchospasm was also noted.

In the control group, atracurium $0.025 \mathrm{mg} \cdot \mathrm{kg}^{-1}$ iv was given as a defasciculating dose together with fentanyl $1 \mu \mathrm{g} \cdot \mathrm{kg}^{-1}$. After preoxygenation for three minutes, thiopentone $4-6 \mathrm{mg} \cdot \mathrm{kg}^{-1}$ was given followed by succinylcholine $1.5 \mathrm{mg} \cdot \mathrm{kg}^{-1}$. Sixty seconds later, the trachea was intubated by a laryngoscopist who entered the operating room only after succinylcholine had been given. The intubating condition was graded accordingly.

All patients were interviewed the day after the operation and specifically asked for weakness, discomfort and overall satisfaction with the technique.

Parametric data from the four groups were compared using one-way analysis of variance (ANOVA) using the statistical programme SPSS for MS Windows release 6.0. Where significant differences were found, the Bonferroni test was used to determine which groups were significantly different from each other. Non-parametric data was analysed using Chi square analysis and Mann U Whitney test. A $P$ value of $<0.05$ was considered to indicate a statistically significant difference.

\section{Results}

Unless otherwise specified, results are presented as mean \pm standard deviation. There were no differences with respect to the age, sex or weight between all four groups. 
TABLE Intubating conditions

\begin{tabular}{|c|c|c|c|c|}
\hline $\begin{array}{l}\text { Intubating } \\
\text { conditions }\end{array}$ & $\begin{array}{l}\text { Group I } \\
\text { Atracurium } \\
0.5 \mathrm{mg} \cdot \mathrm{kg}^{-1}\end{array}$ & $\begin{array}{l}\text { Group II } \\
\text { Atracurium } \\
0.75 \mathrm{mg} \cdot \mathrm{kg}^{-1}\end{array}$ & $\begin{array}{l}\text { Group III } \\
\text { Atracurium } \\
1 \mathrm{mg} \cdot \mathrm{kg}^{-1}\end{array}$ & $\begin{array}{l}\text { Group IV } \\
\text { Succinylcholine } \\
1.5 \mathrm{mg} \cdot \mathrm{kg}^{-1}\end{array}$ \\
\hline 3 & 9 & 17 & 17 & 19 \\
\hline 2 & 11 & 3 & 3 & 1 \\
\hline 1 & 0 & 0 & 0 & 0 \\
\hline 0 & 0 & 0 & 0 & 0 \\
\hline
\end{tabular}

I vs IV: $P<0.0005$. I vs II and III: $P<0.005$.

No Significant difference between II, III and IV.

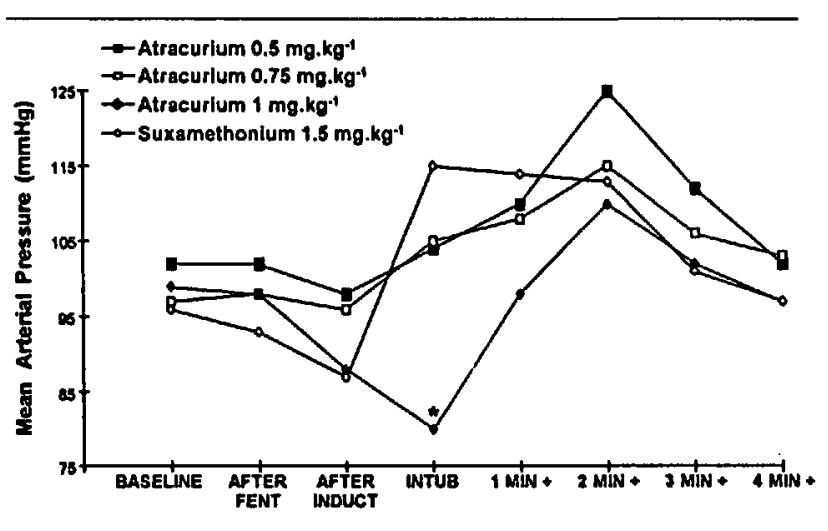

FIGURE 1 Mean arterial pressure $(\mathrm{mmHg})$ following atracurium 0.5 $\mathrm{mg} \cdot \mathrm{kg}^{-1}, 0.75 \mathrm{mg} \cdot \mathrm{kg}^{-1}, 1 \mathrm{mg} \cdot \mathrm{kg}^{-1}$ and succinylcholine 1.5 $\mathrm{mg} \cdot \mathrm{kg}^{-1}$ at: (a) baseline; (2) post-fentanyl; (3) post-induction; (4) postintubation; (5) $1 \mathrm{~min}$ post-intubation; (6) $2 \mathrm{~min}$ post-intubation; (7) 3 min post-intubation; (8) 4 min post-intubation. *Significantly different among groups $(P<0.05)$.

The time required for onset of clinical weakness as assessed by the onset of ptosis was $32.4 \pm 9.3 \mathrm{sec}$ for Group I, $29.0 \pm 1.0 \mathrm{sec}$ for Group II and $28.0 \pm 11.7$ sec for Group III. There were no differences in the onset time of ptosis between the three study groups.

Intubating conditions are summarized in the Table. The intubating conditions for Group I were worse than those in the control, Group IV $(P<0.0005)$ and in Groups II and III $(P<0.005)$. However, there were no differences in intubating scores among Groups II, III and IV.

Compared with the control group, atracurium appeared to counteract the increase in heart rate and blood pressure associated with laryngoscopy and intubation as in Groups I and II (Figures I and 2). However, in Group III, there was a decrease in the blood pressure immediately after intubation, $(P<0.05)$. The mean arterial pressure decreased from a baseline of $98.8 \pm 12.9 \mathrm{mmHg}$ to $80.1 \pm 25.5 \mathrm{mmHg}$, a decrease of $19 \%(P<0.05)$. This decrease did not persist as there was no difference in the mean blood pressure over the next four minutes. Over the same period, the mean arterial pressure for the

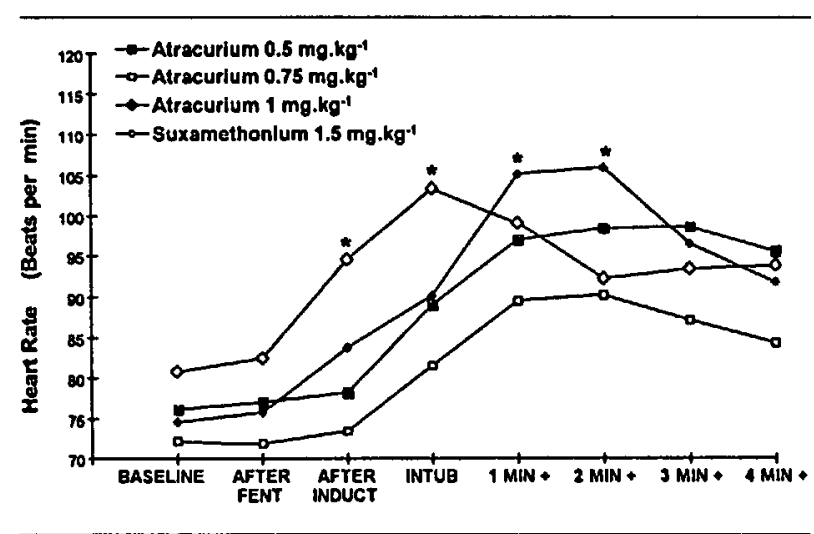

FIGURE 2 Heart rate (beats per min) following atracurium 0.5 $\mathrm{mg} \cdot \mathrm{kg}^{-1}, 0.75 \mathrm{mg} \cdot \mathrm{kg}^{-1}, 1 \mathrm{mg} \cdot \mathrm{kg}^{-1}$ and suxamethonium 1.5 $\mathrm{mg} \cdot \mathrm{kg}^{-1}$ at: (1) baseline; (2) post-fentanyl; (3) post-induction; (4) postintubation; (5) $1 \mathrm{~min}$ post-intubation; (6) $2 \mathrm{~min}$ post-intubation; (7) 3 min post-intubation; (8) $4 \mathrm{~min}$ post-intubation. *Signicantly different among groups $(P<0.05)$.

control group increased from $95.8 \pm 10.6 \mathrm{mmHg}$ to 115.4 $\pm 21.5 \mathrm{mmHg}$, an increase of $20 \%(P<0.05)$. The heart rate, in general, increased after the induction agents were given and the increase lasted for the next three minutes for all four groups.

The heart rate in the control group increased $28 \%$ from the baseline after intubation $(P<0.05)$. For Group III, the maximum increase in heart rate was $40 \%$ from the baseline occurring two minutes after intubation $(P<$ 0.05 ). Group I and II had increases of $30 \%$ and $25 \%$ respectively during this period.

As the dose of atracurium was increased, the incidence of cutaneous flushing also increased $(30 \%(6), 35 \%$ (7) and $60 \%$ (12) for Groups I, II and III respectively). One patient each (5\%) from Groups I and II developed bronchospasm after administration of atracurium but this was self-limiting. None from Group III developed bronchospasm. In Groups I, II and III, 40\% (8), 45\% (9) and $40 \%$ (8) respectively complained of weakness before the onset of anaesthesia. This consisted mainly of the inability to take deep breaths. Three patients felt discomfort but only one patient was dissatisfied with the anaesthetic 
technique. All three patients had previous general anaesthetics. The single dissatisfied patient had had multiple general anaesthetics, received atracurium $1 \mathrm{mg} \cdot \mathrm{kg}^{-1}$ and was very anxious before the operation. She was also the only patient who had a weak cough after atracurium was given before thiopentone induction. All other patients were able to cough normally.

All operations lasted more than one hour and there were no difficulties reversing the neuromuscular blockade with neostigmine.

\section{Discussion}

The timing principle using atracurium three to four times $\mathrm{ED}_{95}$ provided intubating conditions comparable with those after succinylcholine. It was not associated with severe haemodynamic changes and other side effects from histamine release were minimal. The period of time when the patient was at risk of aspiration was similar to that when succinylcholine was used during rapid sequence induction. ${ }^{17}$

The timing principle as described by Culling ${ }^{10}$ utilised a bolus of vecuronium followed by thiopentone timed at the onset of clinical weakness. It attempted to time the onset of peak neuromuscular blockade with the onset of anaesthesia. The induction sequence was thus individualised with respect to the onset of muscle weakness. ${ }^{11}$ In his study, Culling used handgrip strength as an indication of weakness. When we used this method in a pilot study, an unacceptable number of patients became restless and uncooperative before the onset of weakness. When ptosis was used as an indication of the onset of clinical weakness, none of our patients became restless or uncooperative prior to the administration of thiopentone. Recent studies have demonstrated that the onset time of neuromuscular blockade in different muscles differs after the administration of non-depolarising neuromuscular blockers. ${ }^{18,19}$ Donati found that the onset time of vecuronium neuromuscular blockade was longer at the adductor pollicis than at the diaphragm, and the orbicularis oculi onset time approached that of the diaphragm. He suggested that monitoring of orbicularis oculi blockade may be a good guide to diaphragmatic blockade. The faster onset at the diaphragm was postulated to be due to greater muscle blood flow. ${ }^{20}$ The patients in our pilot study probably became restless with the onset of diaphragmatic paralysis causing discomfort. We postulate that the onset time of non-depolarising neuromuscular blockers in the levator palpebrae is comparable with that of the orbicularis oculi so that ptosis developed together with diaphragmatic paralysis leading to more cooperative patients in our study.

Increasing the dose of atracurium did not reduce the onset time for ptosis. Hull stated that the onset time of action for non-depolarising neuromuscular blocker is determined by the cardiac output, circulation time to the muscles, muscle blood flow, tissue-plasma partition coefficient as well as potency of the drug. ${ }^{21}$ We postulate that it only requires a small dose of atracurium to result in sufficient neuromuscular blockade to cause ptosis. Increasing the dose will not reduce the onset time which is dependent on the delivery of the drug to the neuromuscular receptors.

Increasing the dose of atracurium from $0.75 \mathrm{mg} \cdot \mathrm{kg}^{-1}$ $\left(3 \times E_{95}\right)$ to $1 \mathrm{mg} \cdot \mathrm{kg}^{-1}\left(4 \times \mathrm{ED}_{95}\right)$ also did not produce better intubating conditions. At equivalent doses, the conditions obtained were comparable with those obtained by Mirakhur ${ }^{22}$ when atracurium was given after anaesthesia was induced. Casson and Jones ${ }^{23}$ found that with vecuronium, the time to maximum blockade decreased markedly with doses in the one to three times $\mathrm{ED}_{95}$ range, but at doses greater than three times $\mathrm{ED}_{95}$, the time to $100 \%$ blockade did not decrease markedly with increasing dose. They postulated this to be due to the plateau effect of the sigmoidal dose response curve.

There has been concern over the haemodynamic effects from histamine release after atracurium at doses $>0.5$ $\mathrm{mg} \cdot \mathrm{kg}^{-1}$. Scott ${ }^{24}$ found that high-dose atracurium was associated with haemodynamic changes although Mirakhur ${ }^{22}$ did not find any changes in blood pressure and heart rate in doses of atracurium up to $1 \mathrm{mg} \cdot \mathrm{kg}^{-1}$. The use of high-dose atracurium in our study was not associated with severe haemodynamic changes. The mild hypotension after induction in Groups I and II appeared to counteract the hypertension associated with laryngoscopy which was present in the control group. Hypotension was seen mainly in Group III. The decrease in the mean blood pressure was greatest immediately after intubation but this was quickly corrected one minute later. The increases in the heart rate occurred after induction and lasted four minutes. The initial tachycardia was probably a response to the decrease in the blood pressure after atracurium and thiopentone. Subsequently the tachycardia could be a response to laryngoscopy and intubation. Atracurium $0.75 \mathrm{mg} \cdot \mathrm{kg}^{-1}$ appeared to be the most appropriate dosage when haemodynamic changes and intubating conditions were considered.

Shorten et al. found that, in a small group of elderly patients, there was no correlation between plasma histamine concentrations and hypotension. In this study, hypotension was present in both the group receiving atracurium and vecuronium leading the authors to suggest that the hypotension after induction was due to a lack of surgical stimulus rather than an effect of histamine. ${ }^{25}$ The cardiovascular effect of atracurium and histamine is debatable. Adt et al. found that despite $\mathrm{H}_{1}$ and $\mathrm{H}_{2}$ receptor antagonist preventing histamine release and hy- 
potension, there was still a decrease in systemic vascular resistance and increase in cardiac index in patients given atracurium. ${ }^{26}$

Other manifestations of histamine release include flushing and bronchospasm. The incidence of flushing in our series was similar to that obtained by other authors at comparable doses ${ }^{22}$ and was dose related. Flushing is a cutaneous manifestation of a mainly harmless allergoid reaction resulting from skin histamine release ${ }^{27}$ and does not always indicate that plasma histamine concentrations are increased. ${ }^{28}$

The incidence of bronchospasm after atracurium has been reported to vary between 0.2 to $1.5 \%{ }^{29,30}$ We found a much higher incidence in our study which may be due to the small numbers studied. It may also be due to stimulation of an inadequately anaesthetised subject, histamine release or atracurium-thiopentone aggregate which may form when thiopentone and atracurium is injected through the same cannula without adequate saline wash through. ${ }^{27}$ Both cases of bronchospasm resolved spontaneously. We would emphasize the need to exclude asthmatic patients to minimize the incidence of bronchospasm when atracurium is given as a "slug" bolus.

Only one patient in our study was dissatisfied with the timing technique. Silverman et al., ${ }^{11}$ when comparing the timing and priming principles, found that although one patient verbalised weakness during induction, none had any recall of weakness in the postoperative period and all were satisfied with the timing technique. In his study, midazolam $\left(0.03-0.06 \mathrm{mg} \cdot \mathrm{kg}^{-1} i v\right)$ was given five minutes before administration of vecuronium. It would be expected that patients would have had antegrade amnesia $^{31}$ and the finding that patients were satisfied with the technique would be difficult to interpret. We did not premedicate our patients to determine the true extent of patient discomfort and satisfaction in our study. However, we would recommend that if the timing technique is used in patients with previous anaesthetic experience, a benzodiazepine should be used to improve patient comfort and acceptance.

The manufacturer recommends that the maximum dose of atracurium for intubation is $0.6 \mathrm{mg} \cdot \mathrm{kg}^{-1}(2.5$ $\left.\mathrm{ED}_{95}\right)$. These recommendations serve only as guidelines. Use of higher dosages are not prohibited but classified as "unlabelled application." 32 Our use of higher doses of atracurium is justified because when individual variability is considered, doses of three times $\mathrm{ED}_{95}$ of atracurium are required to produce satisfactory intubating conditions. ${ }^{33}$

We did not study the duration of action of high-dose atracurium as this was not the purpose of our study. Previous studies have determined that the duration of action of high-dose atracurium was between $57 \mathrm{~min}$ (1 $\left.\mathrm{mg} \cdot \mathrm{kg}^{-1}\right)^{22}$ and $71 \mathrm{~min}\left(1.5 \mathrm{mg} \cdot \mathrm{kg}^{-1}\right){ }^{32}$ Because of this long duration, we would recommend that the timing technique using high-dose atracurium be limited to surgery lasting more than an hour. It would be inappropriate to use this technique in potentially difficult intubation as neuromuscular blockade can be antagonised only after one hour. Other contraindications include patients at increased risk of gastric aspiration, haemodynamic instability and in asthmatics. The technique is also unsuitable in patients who cannot understand or are uncooperative or are extremely anxious. The conditions for intubation and the haemodynamic changes obtained apply only when atracurium and thiopentone were used. Using other agents, e.g., pancuronium and propofol may produce different results.

\section{References}

1 Lee C. Succinylcholine: its past, present, and future. In: Katz RL (Ed.). Muscle Relaxants: Basic and Clinical Aspects. Orlando, Florida: Grune \& Stratton, 1985; 69-85.

2 Vandenbrom RHG, Wierda JMKH, Huizinga ACT, Hennis $P J$. Intubation conditions and time-course of action of ORG 9426. Anesthesiology 1991; 75: A788.

3 Dubois M, Shearrow T, Tran D, et al. ORG 9426 used for endotracheal intubation: a comparison with succinylcholine. Anesthesiology 1991; 75: A1066.

4 Mehta MP, Choi WW, Gergis SD, Sokoll MD, Adolphson $A J$. Facilitation of rapid endotracheal intubations with divided doses of nondepolarising neuromuscular blocking drugs. Anesthesiology 1985; 62: 392-5.

5 Baumgarten RK, Carter CE, Reynolds WJ, Brown JL, DeVera HV. Priming with nondepolarising muscle relaxants for rapid tracheal intubation: a double-blind evaluation. Can J Anaesth 1988; 35: 5-11.

6 Glass PSA, Wilson W, Mace JA, Wagoner $R$. Is the priming principle both effective and safe? Anesth Analg 1989; 68: 127-34.

7 Musich J, Walts LF. Pulmonary aspiration after a priming dose of vecuronium. Anesthesiology 1986; 64: 517-9.

8 Ginsberg B, Glass PS, Quill T, Shafron D, Ossey $K$. Onset and duration of neuromuscular blockade following highdose vecuronium administration. Anesthesiology 1989; 71 : 201-5.

9 Tullock WC, Diana P, Cook DR, et al. Neuromuscular and cardiovascular effects of high-dose vecuronium. Anesth Analg 1990; 70: 86-90.

10 Culling $R D$, Middaugh RE, Menk EJ. Rapid tracheal intubation with vecuronium: the timing principle. J Clin Anaesth 1989; 1: 422-5.

11 Silverman SM, Culling RD, Middaugh RE. Rapidsequence orotracheal intubation: a comparison of three techniques. Anesthesiology 1990; 73: 244-8. 
12 Payne JP, Hughes $R$. Evaluation of atracurium in anaesthetized man. Br J Anaesth 1981; 53: 45-54.

13 Gordon KL, Reilly CS. Recovery of neuromuscular function after infusion or intermittent bolus doses of atracurium or vecuronium. Br J Anaesth 1989; 62: 269-73.

14 Law Min JC, Bekavac I, Glavinovic MI, Donati F, Bevan $D R$. Iontophoretic study of speed of action of various muscle relaxants. Anesthesiology 1991; 75: A810.

15 Bartkowski RR, Witkowski TA, Azad S, Lessin J, Marr A. Rocuronium onset of action: a comparison with atracurium and vecuronium. Anesth Analg 1993; 77: 574-8.

16 Lund I, Stovner J. Dose-response curves for tubocurarine, alcuronium and pancuronium. Acta Anaesthesiol Scand Suppl 1970; 37: 238-42.

17 Larijani GE, Gratz I, Silverberg $M$, Jacobi $A G$. Clinical pharmacology of the neuromuscular blocking agents. DICP The Annals of Pharmacotherapy 1991; 25: 54-64.

18 Smith CE, Donati F, Bevan DR. Differential effects of pancuronium on masseter and adductor pollicis muscles in humans. Anesthesiology 1989; 71: 57-61.

19 Pansard J-L, Chauvin M, Lebrault C, Gauneau P, Duvaldestin $P$. Effect of an intubating dose of succinylcholine and atracurium on the diaphragm and the adductor pollicis muscle in humans. Anesthesiology 1987; 67: 326-30.

20 Donati F, Meistelman C, Plaud B. Vecuronium neuromuscular blockade at the diaphragm, the orbicularis oculi, and adductor pollicis muscles. Anesthesiology 1990; 73: 870-5.

21 Hull CJ. Pharmacokinetics for Anaesthesia. Oxford: Butterworth-Heinemann, 1991, 333-4.

22 Mirakhur RK, Lavery GG, Clarke RSJ, Gibson FM, $M c$ Ateer $E$. Atracurium in clinical anaesthesia: effect of dosage on onset, duration and conditions for tracheal intubation. Anaesthesia 1985; 40: 801-5.

23 Casson WR, Jones RM. Vecuronium-induced neuromuscular blockade: the effect of increasing dose on speed of onset. Anaesthesia 1986; 41: 354-7.

24 Scott RPF, Savarese JJ, Basta SJ, et al. Clinical pharmacology of atracurium given in high dose. Br $\mathrm{J}$ Anaesth 1986; 58: 834-8.

25 Shorten GD, Goudsouzian NG, Ali HH. Histamine release following atracurium in the elderly. Anaesthesia 1993; 48: 568-71.

26 Adt M, Baumert JH, Reimann HJ. The role of histamine in the cardiovascular effects of atracurium. $\mathrm{Br} \mathrm{J}$ Anaesth 1992; 68: 155-60.

27 Watkins $J$. Histamine release and atracurium. $\mathrm{Br} \mathbf{J}$ Anaesth 1986; 58: 19S-22S.

28 Barnes PK, de Renzy-Martin N, Thomas VJE, Watkins J. Plasma histamine levels following atracurium. Anaesthesia 1986; 41: 821-4.

29 Lawson DH, Paice GM, Glavin RJ, et al. Atracurium - a post-marketing surveillance study: UK study and discussion. Br J Anaesth 1989; 62: 596-600.

30 Jick $H$, Andrews EB, Tilson HH, et al. Atracurium - a post-marketing surveillance study: methods and U.S. experience. Br J Anaesth 1989; 62: 590-5.

31 Dundee JW, Wilson $D B$. Amnesic action of midazolam. Anaesthesia 1980: 35: 459-61.

32 Lennon $R L$, Olson $R A$, Gronert $G A$. Atracurium or vecuronium for rapid sequence endotracheal intubation. Anesthesiology 1986; 64: 510-3.

33 Twohig MM, Ward S, Corall IM. Conditions for tracheal intubation using atracurium compared with pancuronium. Br J Anaesth 1983; 55: 87S-9S. 